\title{
Characteristics of the turbidite fan in the Wenchang Formation of the Enping Sag, Pearl River Mouth Basin, China and its hydrocarbon significance
}

\author{
Chen Guojun $^{1}$, Li Chao ${ }^{1,2 *}$, Du Guichao ${ }^{2}$, Zhang Gongcheng ${ }^{3}$, Lü Chengfu ${ }^{1}$ \\ and Wang Qi ${ }^{1}$ \\ ${ }^{1}$ Key Laboratory of Petroleum Resources Research, Institute of Geology and Geophysics, Chinese Academy of Sciences, \\ Lanzhou, Gansu 730000, China \\ ${ }^{2}$ University of Chinese Academy of Sciences, Beijing 100049, China \\ ${ }^{3}$ Research Institute of China National Offshore Oil Corporation, Beijing 100027, China
}

(C) China University of Petroleum (Beijing) and Springer-Verlag Berlin Heidelberg 2013

\begin{abstract}
A turbidite fan in the Eocene upper Wenchang Formation in the Enping Sag, Pearl River Mouth Basin (PRMB) has been studied using seismic, logging and borehole data. The fan is characterized by parallel progradation on the dip seismic profile and is mound-shaped or lenticular-shaped on the strike seismic profile. The study of the core and logging data from well EP17-3-1, which is located in the front side of the turbidite fan, shows that this fan is a set of normal grading sand beds, interbedded within thick dark grey mudstones of semi-deep to deep lake deposits in the Wenchang Formation. The fan is interpreted as a sand/mud-rich turbidite fan that has an area of over $140 \mathrm{~km}^{2}$ and a maximum thickness of over $340 \mathrm{~m}$. Combined with a study of the regional geological background and previous provenance analysis of the Eocene Wenchang Formation, the main potential provenances for the turbidite fan are considered to be the Panyu low-uplift and northern fault terrace zone. The Enping Sag is considered to be a half graben-like basin whose north side is faulted and whose south side is overlapped. Basement subsidence in the Eocene was mainly controlled by boundary faults which dip relatively steeply on the north side, causing the subsidence center of the Enping Sag in this stage to be close to the north boundary faults. Sustained faults developed in the Enping Sag during the Eocene caused an increase of the relative height difference between the north and the south uplift zone in the Enping Sag. Affected by the second episode of the Zhuqiong movement (39-36 Ma) in late Eocene, sediments which had accumulated on the Panyu low-uplift zone were triggered and moved toward the subsidence center of the Enping Sag and formed the turbidite fan. The second episode of the Zhuqiong movement is the most important triggering factor for the formation of the turbidite fan in the Wenchang Formation. Seismic attribute characterization shows that the low frequency energy is enhanced and high frequency energy is weakened when seismic waves propagate through the oil-bearing zone in this fan. Amplitude versus offset (AVO) anomalies are observed in the seismic data and abnormally high pressure is encountered. The turbidite fan in the Wenchang Formation has provided important information for sedimentary evolution in deep layers of the Enping Sag and pointed to a new direction for the hydrocarbon exploration in the study area.
\end{abstract}

Key words: Pearl River Mouth Basin, Enping Sag, Wenchang Formation, turbidite fan, hydrocarbon exploration

\section{Introduction}

Hydrocarbon exploration in deep-water basins has become an important and active field for the global oil and gas industry, since turbidite sandbodies were found to be important oil and gas reservoirs in the 1950s (Wu, 1986; Pang et al, 2006; 2007). Deep-water turbidite fans are not only one

*Corresponding author. email: lichaomails@163.com

Received May 11, 2012 of the main focuses in global hydrocarbon exploration, but also a frontier in sedimentological studies in recent years (Zhu et al, 2004; Chen et al, 2007; Wang et al, 2011). An estimated 1,200 to 1,300 oil and gas fields, including producing fields, are known from deep-water turbidites and related systems (Stow and Mayall, 2000). Pettingill (1998) documented 925 of these fields (excluding carbonate plays) from 54 basins, of which 43 fields could be classified as giants $(>500$ million barrels oil equivalent). Turbidite reservoirs are also widely discussed in China (Lai and Gu, 1984; Gao and Wu, 
1985; Lei et al, 1999; Bai and Zhang, 2004; Liu et al, 2006). Deep-water hydrocarbon exploration for submarine fans has achieved great success in the Pearl River Mouth Basin in the northern slope of the South China Sea in recent years, and a large submarine fan was discovered in the Baiyun Sag. The deep-water fan has been proved to be prolific by wells drilled on the LW3-1 structural trap (Pang et al, 2006; 2007; Wang et al, 2011; 2012; Zhu et al, 2012). So, are there turbidite fans developed in the Enping Sag? It is necessary to study the known turbidite fan and its formation time, distributing features, the characteristics of associated sands developed in this fan and the main controlling factors for its formation. It is important to find the answers which will significantly contribute to understanding the sedimentary evolution and the directions for hydrocarbon exploration in the Enping Sag.

The turbidite fan in the upper strata of the Eocene Wenchang Formation has been studied on the basis of previous research on the regional tectonics and sedimentary background, through seismic data interpretation wellseismic calibration, well data, combined with seismic reflection characteristics, seismic facies and drilling cuttings analysis. The tectonic background, provenance, sedimentary environment and the main factors controlling the formation of turbidite fan and its depositional model were studied. Finally, we integrated seismic reflection attributes such as frequency and amplitude, AVO analysis and formation pressure testing to analyze the hydrocarbon potential of the turbidite fan, and pointed out the directions for hydrocarbon exploration in the study and adjacent area.

\section{Geological setting}

\subsection{Structural geology and tectonics}

The Enping Sag is located in the west of the Zhu I Depression, which is situated on the northern margin of the Pearl River Mouth Basin (Fig. 1). This sag is a half grabenlike basin, with an area of about $5,100 \mathrm{~km}^{2}\left(2,200 \mathrm{~km}^{2}\right.$ for the Paleogene) and a depositional thickness of over 8,000 m (Huang, 1999; Fu et al, 2007; Chen et al, 2008). Affected by multiple tectonic movements, the geological evolution of the basin can be divided into four tectonic stages: 1) prerifting stage, 2) rifting stage between the late Cretaceous and the early Oligocene, 3) depression stage during the late Oligocene to the early Miocene, 4) block faulting stage from the late Miocene to the present (Huang, 1999; Li, 1999; Zhuo et al, 2007; 2008; Zhang, 2010). The Wenchang Formation, deposited in the Eocene, is typical in the main rifting stage.

The Pearl River Mouth Basin has experienced several phases of tectonic movements. Affected by the Shenhu movement, the NE-EW main faults were generated and activated, and the Enping Sag was initially formed during the late Cretaceous $\left(\mathrm{K}_{3}\right)$ to Paleocene. The main faults were further activated as the first episode of the Zhuqiong movement occurred during the early to middle Eocene $\left(\mathrm{E}_{2}{ }^{1-2}\right)$, and the amplitude of the faults increased rapidly in this period. Correspondingly, the water depth in the Enping Sag increased and fluvial-lacustrine facies of the Wenchang Formation was deposited in the basin center. The Enping Sag was uplifted and denuded as the second episode of the Zhuqiong movement occurred during the late Eocene to early Oligocene $\left(\mathrm{E}_{2}{ }^{3}-\mathrm{E}_{3}{ }^{1}\right)$, with the sag continuously extending and faults further developed in this period. Correspondingly, the lake area of the Enping Sag was bigger and its water depth was much shallower than that of the Wenchang Formation, and at this time the sag deposited the fluvial-lacustrine facies of the Enping Formation. After that, the Enping Sag entered

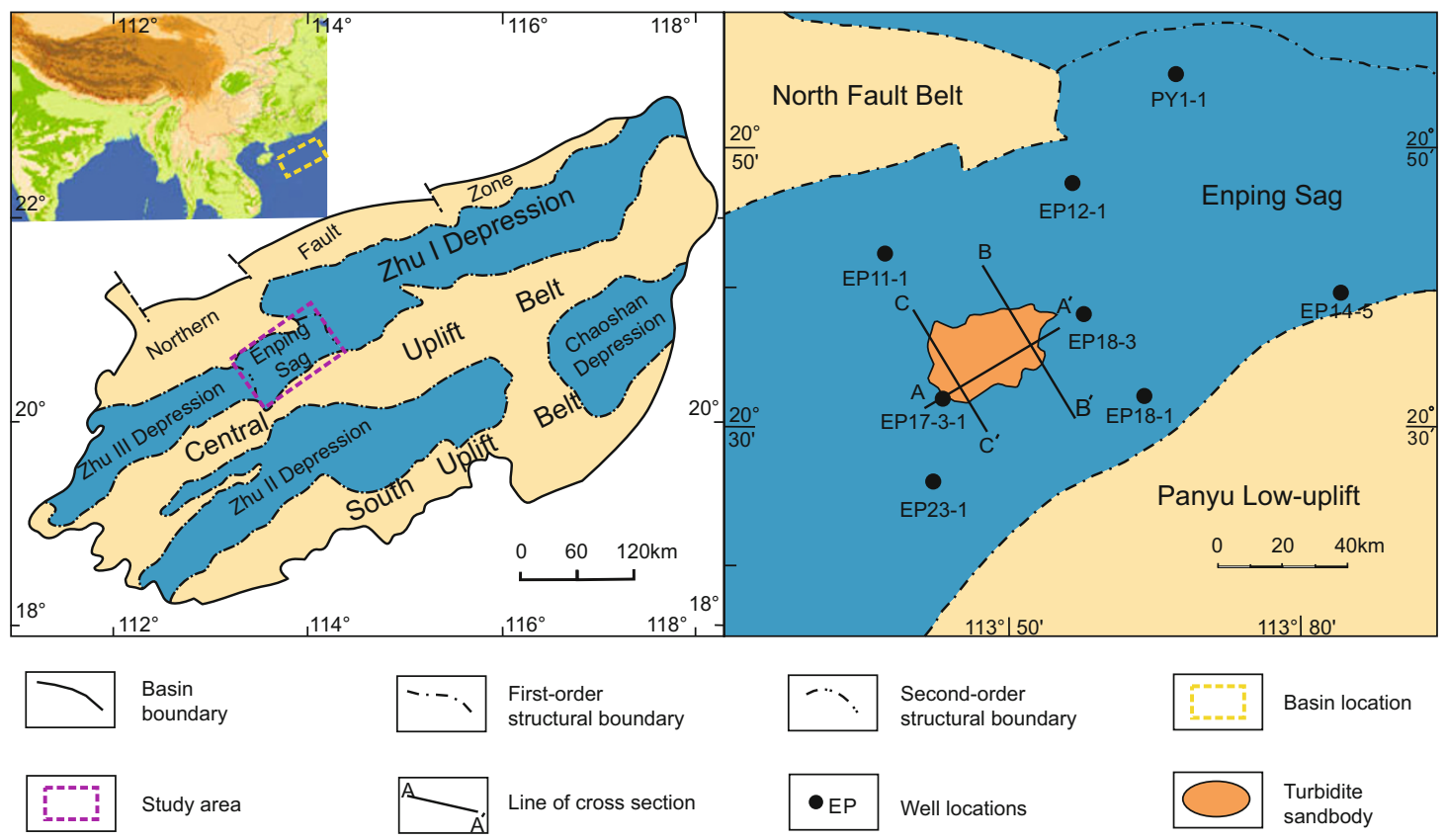

Fig. 1 Left: Tectonic division of the Pearl River Mouth Basin and location of the study area Right: The distribution of the turbidite fan in the Wenchang Formation of the Enping Sag 
the post-rifting stage roughly from the late Oligocene to the present. Seawater entered the Enping Sag during the late Oligocene Zhuhai sedimentary stage and progradation of paleo-Pearl River Delta reached the study area, depositing the transitional and deltaic facies of the Zhuhai Formation in the littoral background. The open-sea basin was formed in the middle Miocene, and thick mudstone was the dominant sediment which is good cap formation (Miao et al, 2010).

In summary, the Enping Sag experienced rifting and post-rifting stages, which are separated by an unconformity interface (T70) formed by the Nanhai movement in the late Oligocene. The depositional environment of the sag evolved from terrestrial facies to marine facies. In the rifting stage continental facies are deposited in the Wenchang and Enping formations. During the post-rifting stage, the Zhuhai Formation was in a terrestrial-marine environment, while the Zhujiang, Hanjiang and Wanshan formations deposited in marine facies.

\subsection{Stratigraphy of the Wenchang Formation}

The Eocene Enping Sag is a strongly separated rifting basin, which corresponds, in part, to the second tectonic stage of basin evolution (Wenchang Formation, typically deposited in the main rifting stage). This sag experienced strong rifting and subsiding processes affected by the first episode of the Zhuqiong movement during early to middle Eocene $\left(\mathrm{E}_{2}{ }^{1-2}\right)$. The Eocene Wenchang Formation unconformably contacts the underlying Shenhu Formation and records lacustrine facies during the deepening of the lake in the basin center. Semi-deep to deep lake deposits typically developed in the center of the Enping Sag, are mainly grayish black mudstones interbedded with fine sandstones and intercalated with coals. The maximum thickness of the Wenchang Formation, the main source rocks of the sag, is generally about 3,000 m (Fig. 2).

The Wenchang Formation sediments are characterized by coarse-fine-coarse grains in the vertical direction, for example, drilling the Wenchang Formation at 4,570-4,864 $\mathrm{m}$ in well EP17-3-1 revealed 213 m black mudstones (Fig. 3 ). The upper and lower was the low-frequency continuous high amplitude seismic facies, and the middle was blank with weak reflection. The low-frequency continuous high amplitude deposits in the Wenchang's upper and lower segments are considered as mudstones interbedded with thin sandstones, while the middle is pure sandstone ( $\mathrm{Li}, 1999$ ). Miao et al (2010) suggested that the well H2 had the same characteristics as the Wenchang Formation sequence (Fig. 4).

\subsection{Sedimentary facies of the Wenchang Formation}

Miao et al (2010) pointed out that the top and bottom interfaces of the Wenchang Formation at the edge of the depression are unconformity surfaces, but the surfaces are conformable in the central depression. Three facies of the Wenchang Formation are recognized. The bottom facies is alluvial fan - fan delta, the center is transitional littoral and shallow lake - semi-deep lake, and the top is fan-delta - littoral and shallow lake. Affected by provenance, water, and later erosion, different sags have different depositional environments. The semi-deep lake seismic facies are characterized by low-frequency, continuous and high amplitude, and the lithology primarily consists of mudstone, interbedded with thin layers of muddy sandstone and siltstone. The logging curves show high acoustic values and high gamma values with finger-like features. The Wenchang Formation of the Enping Sag mainly develops semi-deep lake and shore-shallow lacustrine source rocks (Fu et al, 2007).

The Wenchang Formation in seismic profiles (Fig. 5) from the EP17 sub-sag presented sub-parallel, moderatecontinuous, low-frequency and moderate-high amplitude reflection characteristics, indicating that the semi-deep lake facies may be developed. The EP18 sub-sag presented continuous, low-frequency and moderate-high amplitude reflection characteristics (Fig. 6), also indicating semideep lake facies. Based on borehole, logging and seismic data analysis, deltaic and lacustrine facies were identified in the Wenchang Formation of the Enping Sag. Deltaic facies

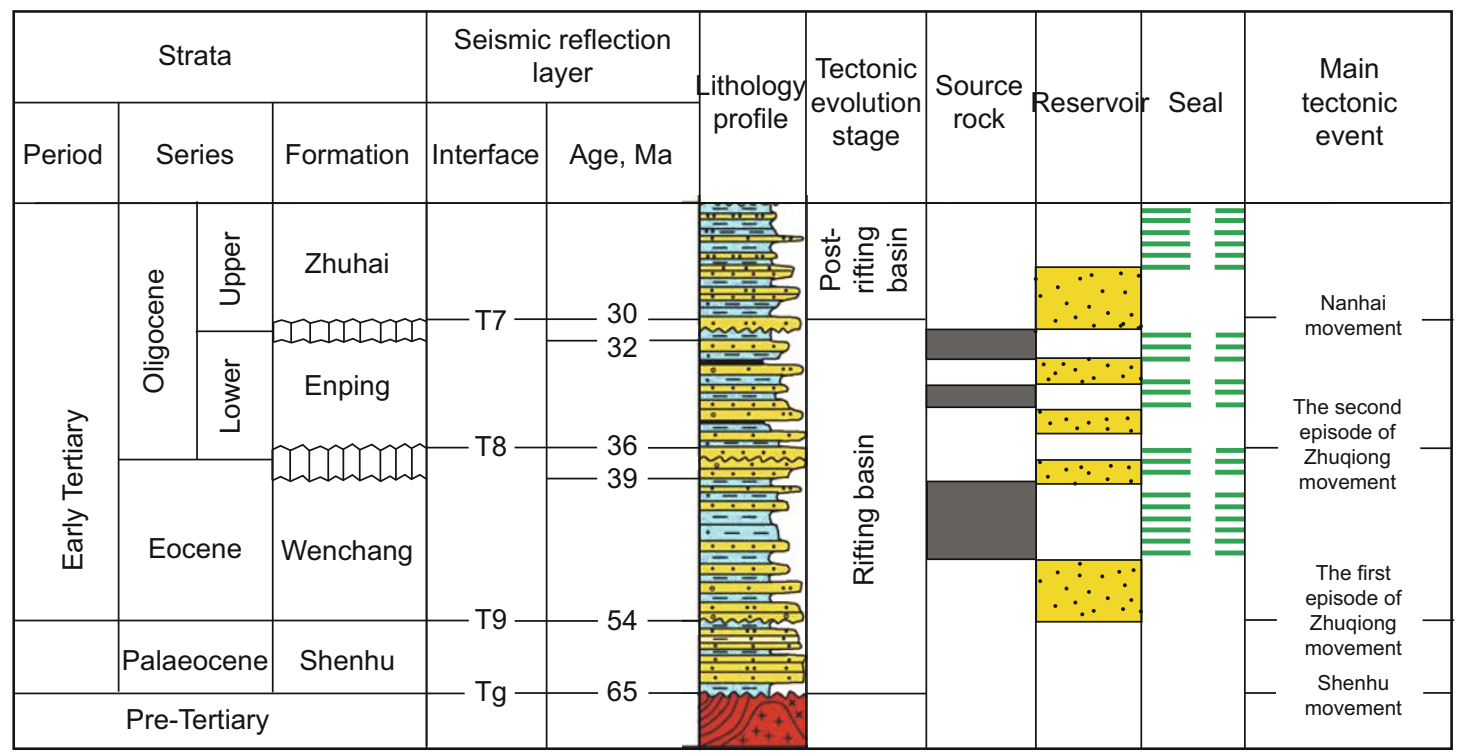

Fig. 2 Early Tertiary stratigraphic section of the Enping Sag of the Pearl River Mouth Basin 


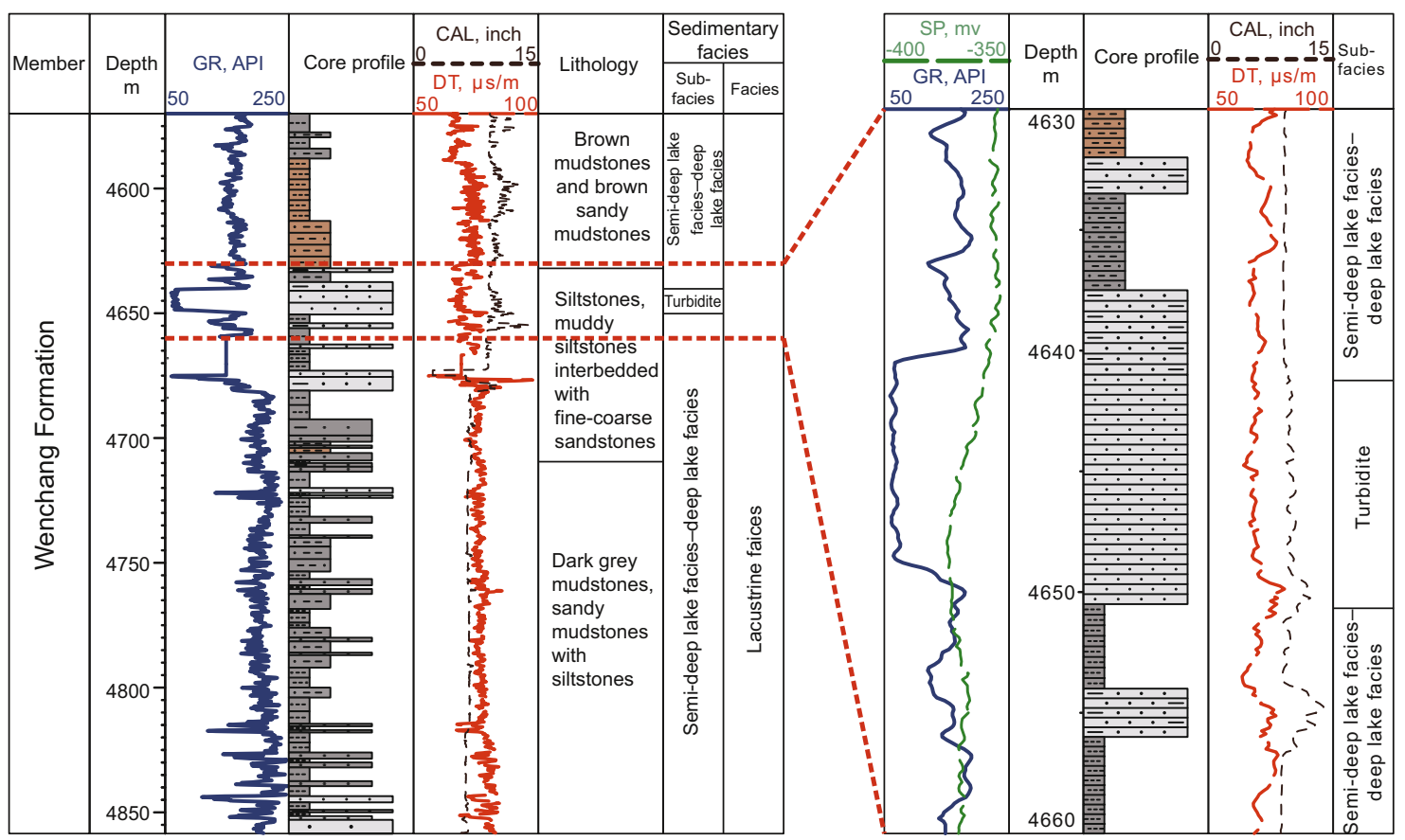

Fig. 3 Lithologic column, log response and lithology descriptions of the Wenchang Formation from well EP17-3-1 of the Enping Sag, Pearl River Mouth Basin. Right: the section illustrating the typical facies and vertical relationships between the turbidite fan and semi-deep and deep lake facies in the Wenchang Formation

mainly developed on the north and south sides of the Enping Sag and lacustrine facies typically developed in the center of the sag (Fig. 7). Basin modeling analysis indicates that the area of the Wenchang Formation is about $1,500 \mathrm{~km}^{2}$, in which the semi-deep and deep lake facies accounts for $415 \mathrm{~km}^{2}(\mathrm{Li}$, 1999; Fu et al, 2007). Affected by the first episode of the Zhuqiong movement, the faulted lake basin further subsided and the lake expanded, and in the basin center the semi-deep and deep lake facies deposited (Fig. 7). The semi-deep and deep lake facies is mainly a set of relatively thick dark grey, greyish black mudstones, interbedded with sandstones and fine sandstones. The drilling of the well EP17-3-1 reached the Wenchang Formation and revealed $294 \mathrm{~m}$ strata, of which the thickness of dark mudstones is $216.5 \mathrm{~m}$. In addition, well EP17-3-1 penetrated the front side of the turbidite fan (Fig. 1). Logging data from well EP17-3-1 show that deposits in the Wenchang Formation are characterized by high gamma and acoustic values. The gamma curve is straight and is close to the shale line with finger-like features, indicating that the Wenchang Formation belongs to semi-deep to deep lake deposits (Fig. 3).

\section{Occurrence of the turbidite fan}

\subsection{Seismic facies characteristics}

On seismic profiles, the turbidite sandbody is wedgeshaped on the dip profile and hummocky or lenticular-shaped on the strike profile. The seismic facies show high amplitude, moderate frequency and good continuity. Typically, the sandbody is characterized by layered deposition and oblique, progradational reflection configuration along the dip direction (Fig. 8). This unit is interbedded within a set of dark grey mudstones and is distributed approximately between well EP17-3-1 and well EP18-3 from NW to SE. It is slightly irregularly fan-shaped, of which the area is about $140 \mathrm{~km}^{2}$ and the maximum thickness is approximately $340 \mathrm{~m}$ (Fig. 1).

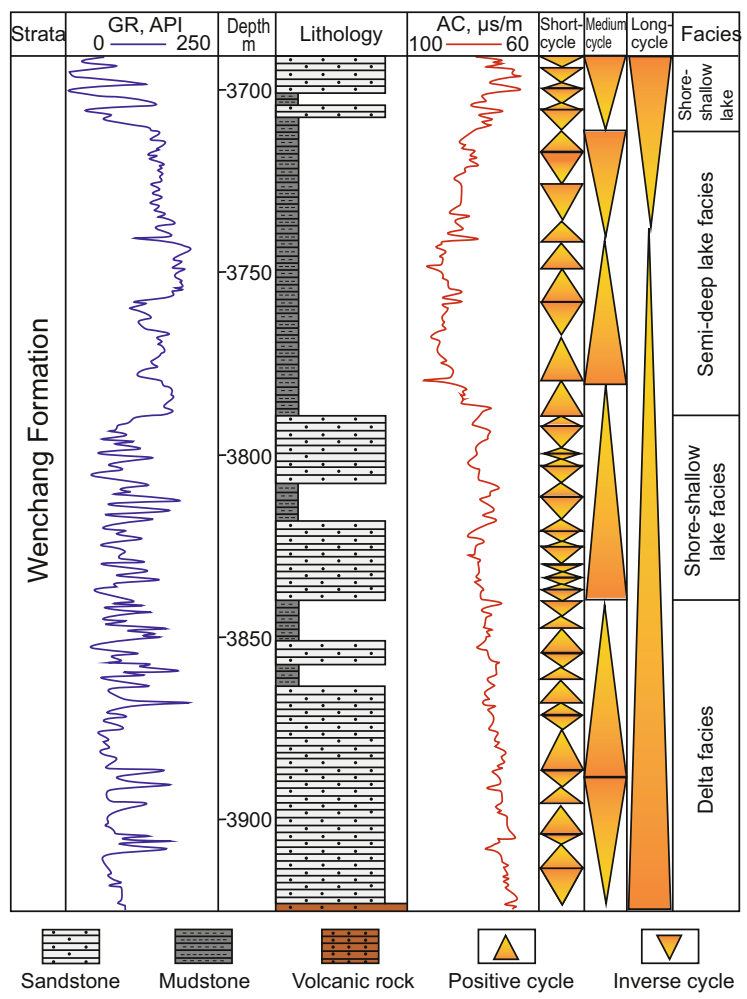

Fig. 4 The sequence and sedimentary facies analysis of well $\mathrm{H} 2$ in the Wenchang Formation (Miao et al, 2010) 


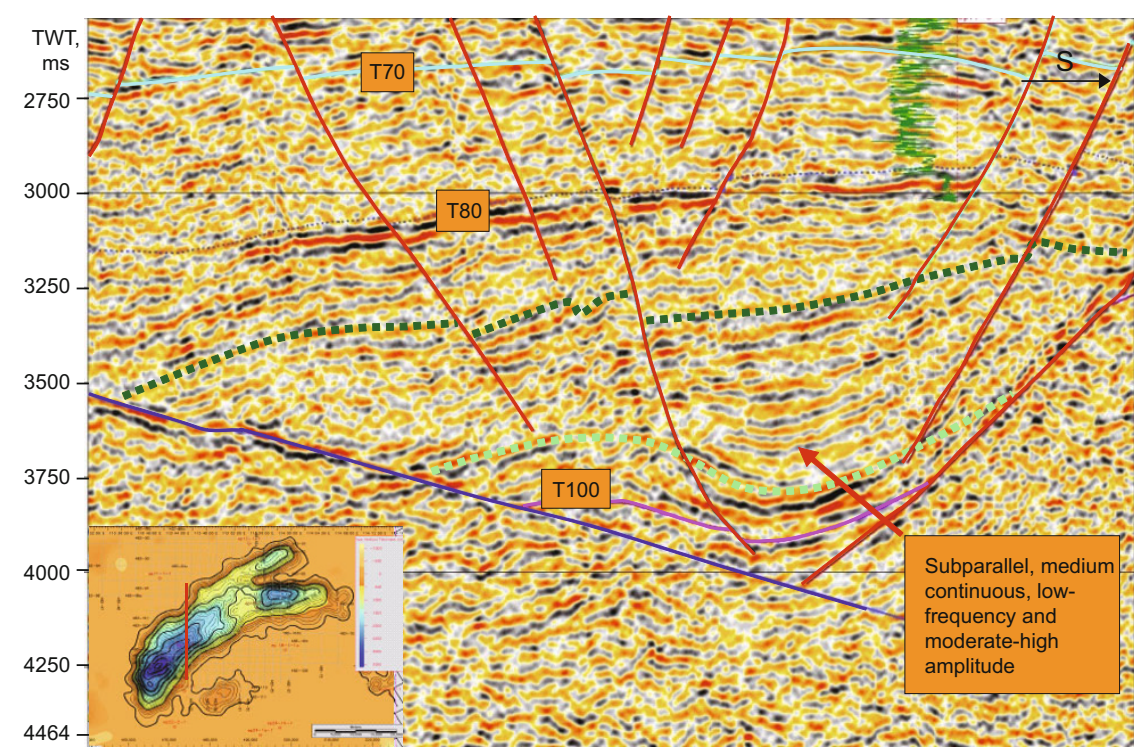

Fig. 5 Seismic reflection characteristics of the Wenchang Formation in the EP17 sub-sag

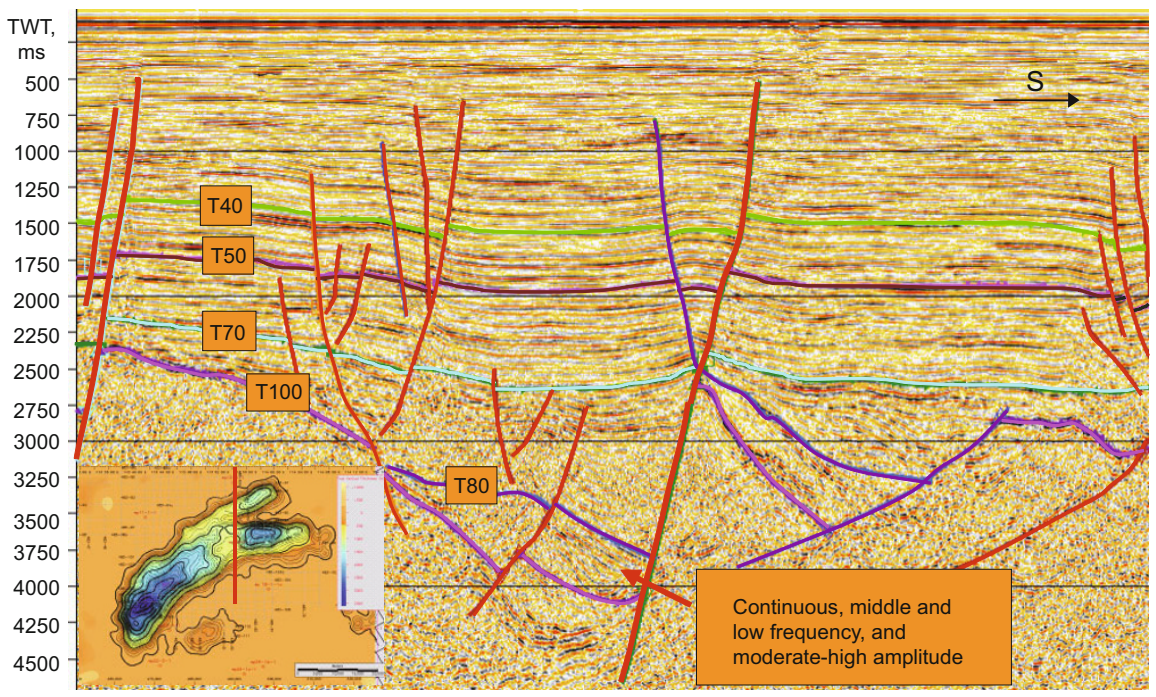

Fig. 6 Seismic reflection characteristics of the Wenchang Formation in the EP18 sub-sag

\subsection{Lithological characteristics}

The well EP17-3-1 penetrated the front side of the turbidite fan and revealed $9 \mathrm{~m}$ sandstones, which were interbedded within thick mudstones. Debris samples and thin sections analyses show that sandstones of this fan are middle to coarse grained, poorly sorted, poorly rounded and infilled by argillic matrix in intergranular pores. Carbonate cements are present in debris samples and inclusions are rarely seen in quartz grains. Diagenetic observation shows that quartz overgrowths and clay coatings occur widely. Feldspars were slightly sericitized (Fig. 9). The turbidite fan primarily consists of muddy and calcareous sandstones. Huang (1999) showed that well EP17-3-1 penetrated the turbidite fan and revealed mainly brown, gray and dark gray mudstone, which was interbedded with low maturity sandstone.

\subsection{Major controls on the turbidite fan sedimentation}

Great progress has been made in studying the distribution, morphology and microfacies of turbidite fans and their oil and gas exploration since 1950s (Wu, 1986; Redin, 1991; Reading and Richards, 1994), especially in submarine fans, and a wide variety of development models of ancient and modern submarine fans have been proposed (Shanmugam, 2000; 2002). The turbidites not only exist in the form of submarine fans, but also in valleys and channel fill, slumping, lobes, sheet-like sands, coated sands, wedge and continental slope accumulation complexes (Wu, 1986; Walker, 1992; Viana et al, 2003). Although the original concept of turbidites was established from lakes, the level of research into lacustrine turbidites is far less than that of submarine turbidites $(\mathrm{Wu}$, 1986; Feng et al, 2010).

We studied the initialization and growth process of the lacustrine turbidite developed in the Wenchang Formation of the Enping Sag from the aspects of provenance, topography, triggering factors and preservation.

\subsubsection{Provenance analysis}

The Enping Sag is a strongly separated rifting basin 
which hosts the Eocene Wenchang Formation (Fig. 1, Fig. 7). From geological background analysis of the formation and distribution of the turbidite fan, it seems that there are two potential provenances for the sediments: the north uplift zone in the north side of the Enping Sag and the Panyu low-uplift in the south side.

In the early stage of the formation of the Enping Sag, the north uplift zone was uplifted to a relatively low extent, providing a small amount of deposits (mainly fine grained) for the Enping Sag. Correspondingly, the Wenchang Formation

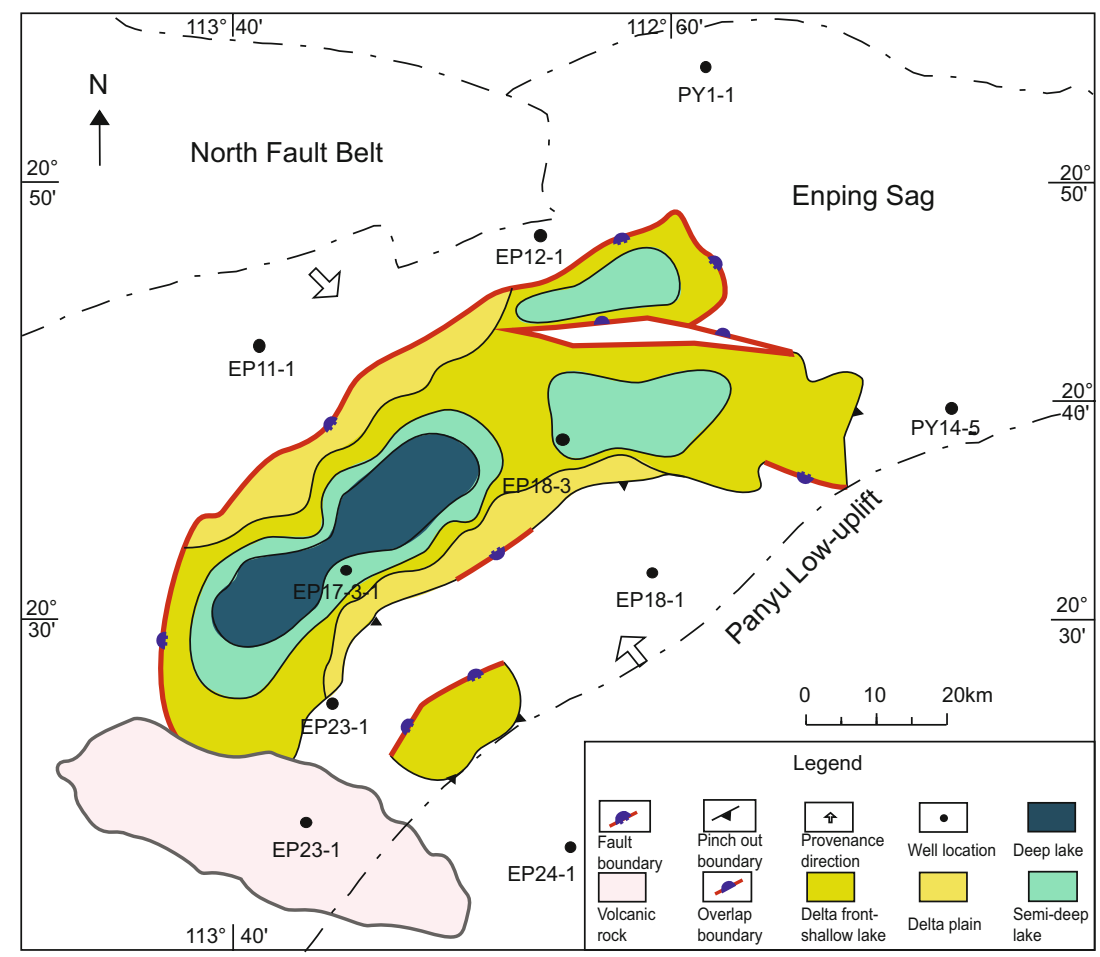

Fig. 7 Palaeogeographic map of the Wenchang Formation in the Enping Sag
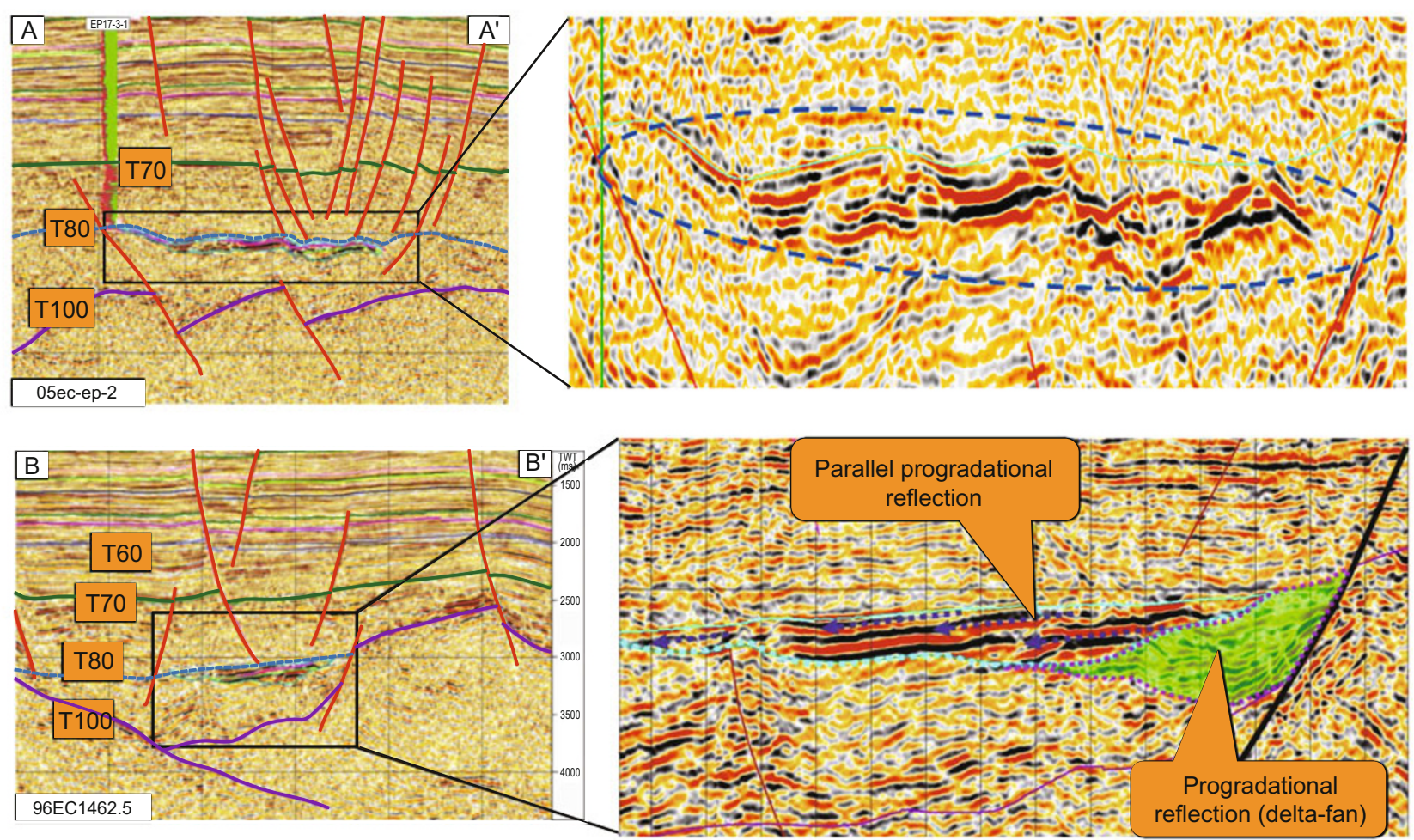

Fig. 8 Typical seismic profiles showing the characteristics of the turbidite sandbody. A-A' profile: lenticular-shaped on the strike direction profile; B-B' profile: parallel progradation on the dip direction profile. Location of profile shown in Fig. 1 

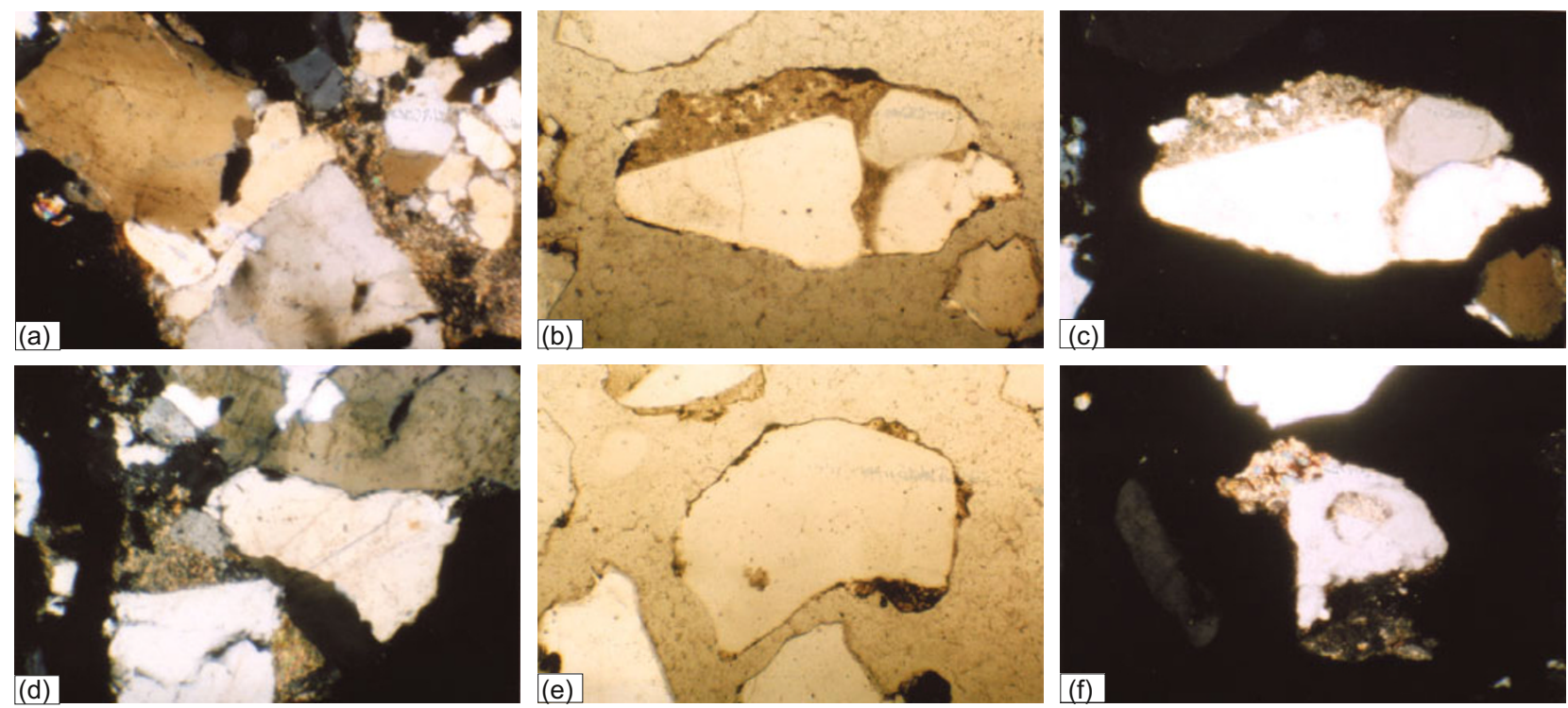

Fig. 9 Debris samples of the turbidite fan from well EP17-3-1.

(a): 4,652 $\mathrm{m}$, detrital grains with poor sorting and rounding, intergranular pores are cemented by calcite and mud in the manner of basal cementation, X-Nicols, $\times 80$. (b): $4,645 \mathrm{~m}$, poor sorting, the quartz overgrowths and intergranular pores are filled by clay matrix, single polar, $\times 80$. (c): the same as (b), X-Nicols, $\times 80$. (d): 4,652 m, detrital grains with poor sorting and rounding are strongly compacted with line contacts and concave-convex contacts, feldspars were slightly sericitizated and intergranular pores are filled by clay matrix, no inclusions in quartz grains, X-Nicols, $\times 80$. (e): $4,645 \mathrm{~m}$, chlorite coatings cover the quartz grains, single polar, $\times 80$. (f): $4,645 \mathrm{~m}$, feldspars were slightly sericitizated, X-Nicols, $\times 80$

was mainly mudstone, and had a low deposition rate in this stage. Then, the height difference increased between the north uplift zone and the depositional center, and the Enping Sag rifted further, which caused an increase of erosion in the north uplift zone. So fluvial and deltaic deposits (mainly fine grained) which predominately accumulated in the north uplift zone are the major source for the deposition of the Wenchang Formation.

Based on the analysis of seismic reflection characteristics and distribution of the turbidite fan, this fan develops close to the Panyu low-uplift (southern side of the Enping Sag) and shows wedge-shaped, oblique, progradation reflection and thins out from the Panyu low-uplift to the basin center (SE-NW) (Fig. 8, B-B'). All these observations suggest that the Panyu low-uplift is the main source of the turbidite fan in the Wenchang Formation. In addition, Huang (1999) studied the drilling data and seismic facies of the Wenchang Formation, and concluded that the Panyu low-uplift is the primary supplying source for alluvial fan and braided river depositional system.

\subsubsection{Morphology analysis}

In a variety of tectonic-stratigraphic settings, slope topography has been demonstrated to playing a major role in sediment routing and deposition (Jackson et al, 2008). Generally, the sediments at a higher rate of sediment supply and deposition may slide basinward more easily than those at a lower rate of sediment supply. Typically, the coarser or more irregular the clastic grains, the more easily the sediments would slide basinward.

Affected by the Shenhu movement and the second episode of the Zhuqiong movement, faults developed in Eocene are mainly boundary faults and minor small faults (Fig. 10). The continuous activity of boundary faults caused further subsidence of the sag. Intra-basin structure shows that, because of fast subsidence of the north side, the north side is lower than the south side in the Enping Sag in this stage. The fast accumulation of fluvial-deltaic sediments between the Panyu low-uplift and the Enping Sag promoted the formation of slopes. With increasing clastic sedimentation, the sediments can slide in topographically unstable areas of the slope and be transported basinward by gravity flow and finally deposit in the semi-deep lake-deep lake environment.

\subsubsection{Triggering conditions}

Turbidites result from sudden gravity-flows. The process commonly occurs when sediments accumulate on the margin of basin and are thick enough. The sediments slide down the slope once the weight of the sediments exceed their shear strength. If there were earthquakes, tsunamis, waves, storm flows and fault activities when the sediments are at the critical sliding stage, the sediments will be easily transported down the basin slope and form turbidite flows.

The formation of the turbidite fan in the Wenchang Formation mainly resulted from the second episode of the Zhuqiong movement, which was one of the main tectonic movements in the early Tertiary, which occurred in the late Eocene and early Oligocene (39-36 Ma). This tectonic movement, lasted for about $3 \mathrm{Ma}$, caused substantial denudation in the study area associated with faulting and magmatism. The basin rifting, affected by the second episode of the Zhuqiong movement, opened the connection between the south of Pearl River Mouth Basin and the sea. In addition, the lake of the Enping Sag expanded gradually in this stage (Wang et al, 2011). In the late depositional stage of the Wenchang Formation, the basement subsidence of the Enping Sag was mainly controlled by boundary faults in the north side, which dip relatively steeply and the subsidence center in this stage was close to the northern boundary faults. Typically, the intra-basin structure shows that the north is lower than the 
south of the Enpin Sag in this stage. Affected by the second episode of the Zhuqiong movement in the late Eocene, the early fan delta sediments which accumulated on the Panyu low-uplift zone were triggered by tectonic factors and moved to the subsidence center of the Enping Sag, finally forming the turbidite fan.

\subsubsection{Preservation conditions}

Generally, turbidite sediments are preserved below the wave base, and reworked by complicated water flows above the wave base. Previous studies indicate that turbidite fans typically developed in deepwater lake or marine environments. Sedimentary studies in this study area show that the water depth of the Enping Sag in Eocene is relatively deep, and semi-deep and deep lake facies developed in the basin center. The sediments primarily consist of mudstone and silty mudstone with a low depositional rate. The deepwater environment helps greatly in forming and preserving the turbidite fan.

\section{The perspective of petroleum exploration of the turbidite fan}

\subsection{Analysis of oil-bearing properties}

Seismic attribute technology provides a useful tool in reservoir forecasting and oil-bearing property evaluations, which extracts optimal composite attributes from a variety of conventional seismic attributes to detect reservoir features. Appropriate use of seismic attribute analysis can greatly reduce the uncertainty of reservoir property prediction in target areas without drilling and can help for estimating hydrocarbon properties or making reservoir management decisions.

Meanwhile, AVO attribute analysis has been proved to be effective in detecting the oil-bearing properties in sandstone reservoirs, and is applied in the prediction of oilbearing zones. The result shows that abundant hydrocarbon bright spots and AVO anomalies are reflected on the seismic data of the turbidite fan (Fig. 11), revealing that this fan is a promising oil-bearing prospect.

The oil-bearing properties of this turbidite fan were firstly detected by extracting low frequency and high frequency of the seismic waves when propagating through the oilbearing zone in this fan. The results show that the low frequency energy $(0-20 \mathrm{~Hz})$ of the oil-bearing zone in this fan is enhanced, its frequency decreases and absorption coefficient increases (Fig. 12). While the energy of the high frequencies $(20-50 \mathrm{~Hz})$ weakens, which is a typical oilbearing characteristic.

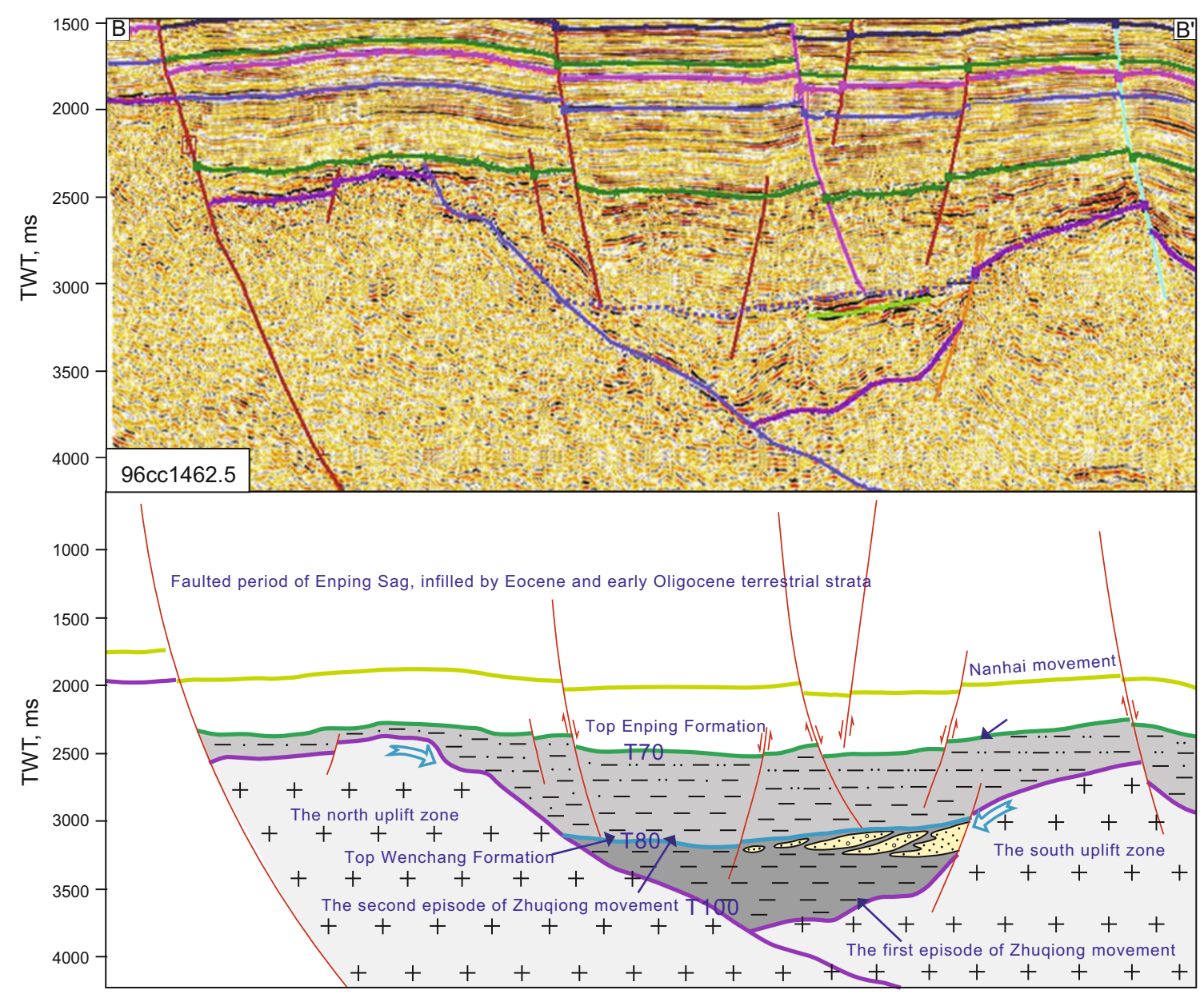

Fig. 10 Schematic reconstructions of the Enping Sag during Eocene and early Oligocene, illustrating the development and evolution of Eocene strata. The reconstruction is based on the seismic section B-B', shown in Fig. 1 


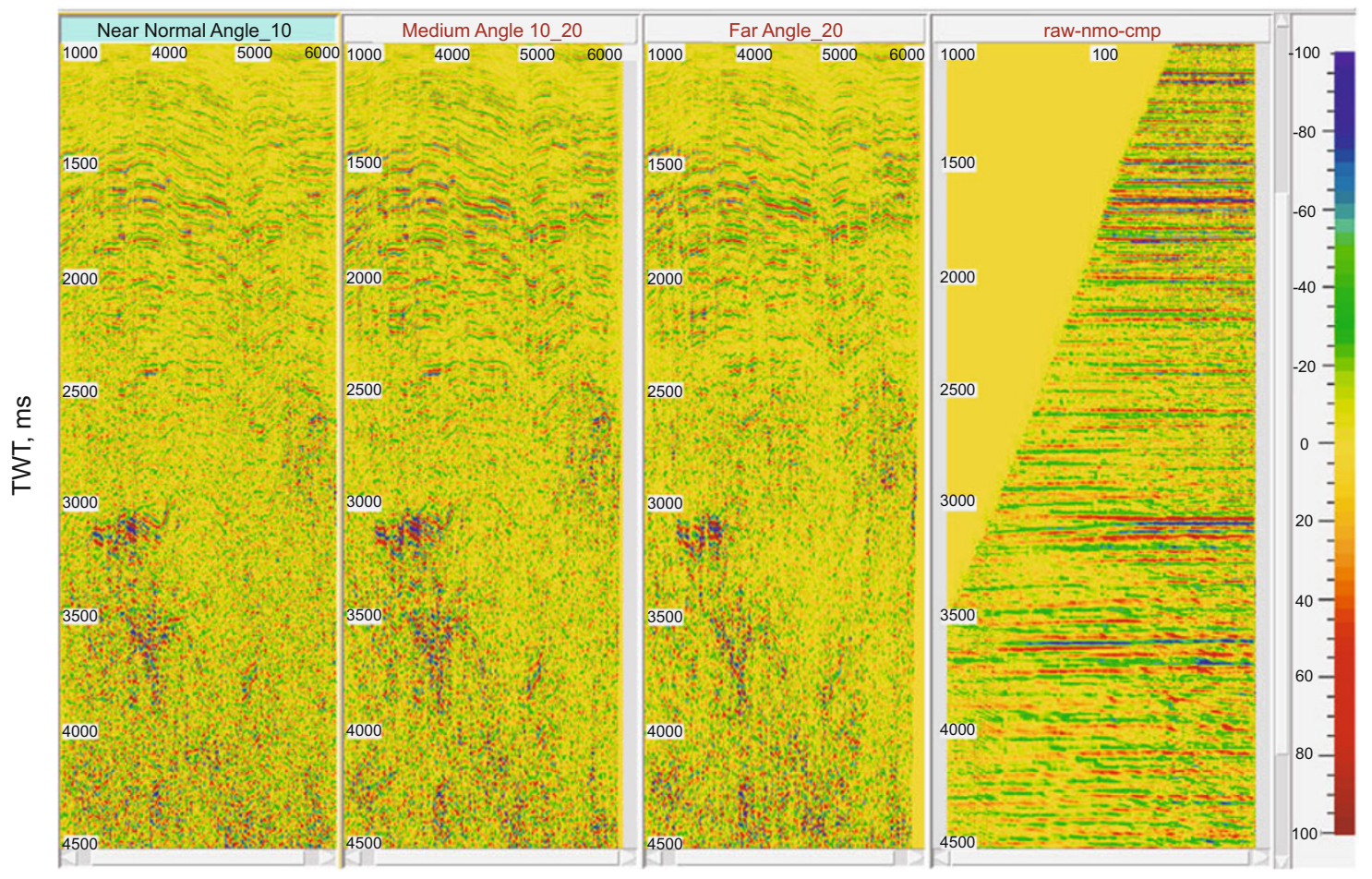

Fig. 11 Bright spots and AVO anomalies in turbidite in well EP17-3 (line 05EC_Ep2)

Well EP17-3-1 penetrated the front side of the turbidite fan and provided useful information for its reservoir property evaluations. Abnormally high pressure are encountered at 4,552-4,642 $\mathrm{m}$, which is the interval in which the turbidite fan developed. The pressure coefficient increases sharply as high as 1.5 in this interval (Fig. 13).

\subsection{Analysis of reservoir forming conditions}

In the Eocene, the Enping Sag was a strongly separated rift basin, where the lacustrine facies of the Wenchang Formation deposited in a semi-deep to deep lake environment.
Paleontology and geochemical studies show that thick mudstones in the Wenchang Formation are the main source rocks in the Enping Sag (Jiang and Yang, 2000). On one hand, source rock characterization shows that organic matter is abundant in this set of lacustrine deposits, with a TOC content of over $2 \%$ and the chloroform bitumen $\mathrm{A}$ is over $0.1 \%$ (Huang, 1998). In short, the favorable hydrocarbon generating potential of source rocks provides prospective conditions for reservoir formation.

On the other hand, abnormally high pressure is one of the main factors that commonly help improving the

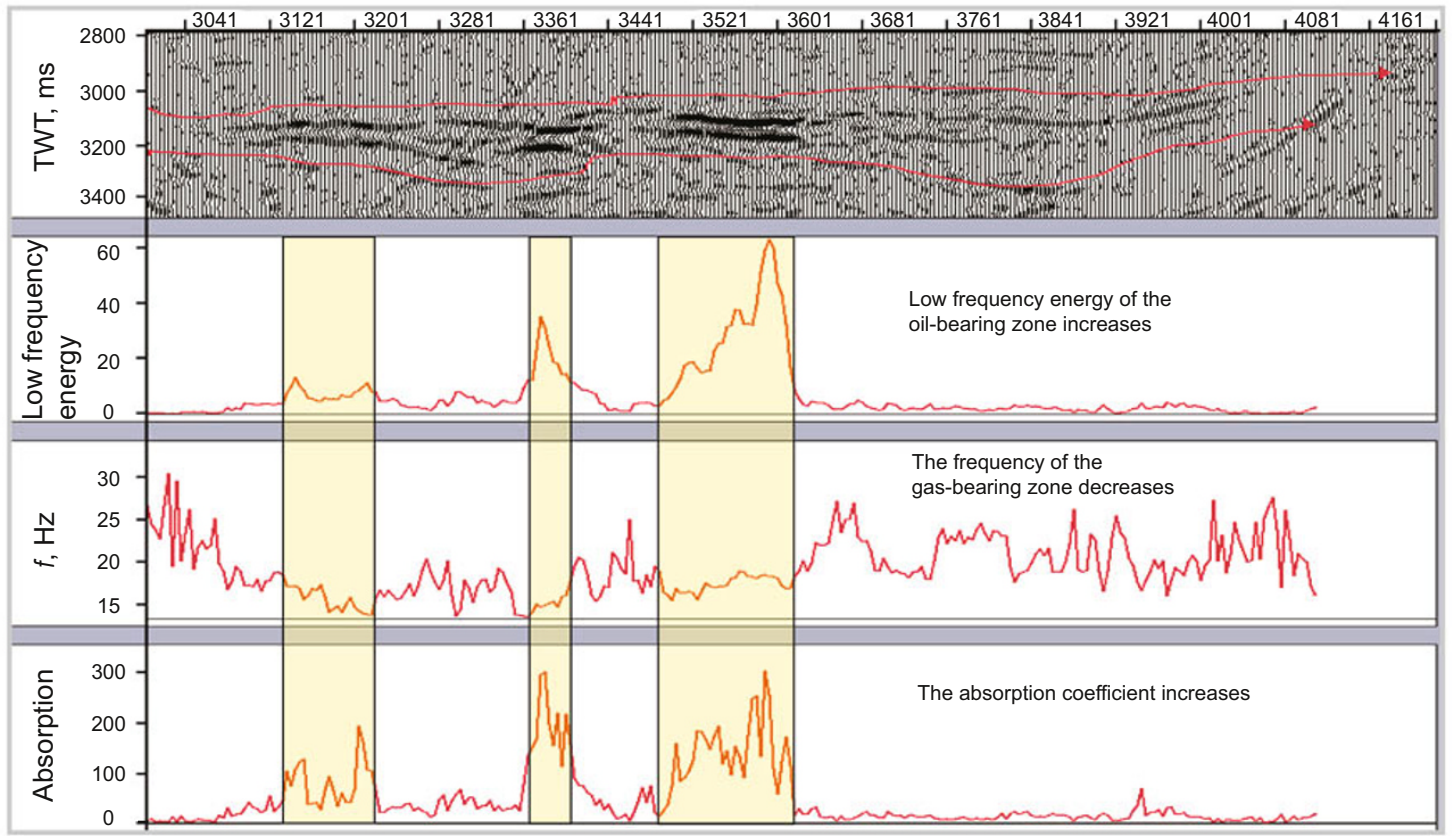

Fig. 12 Detection of oil-bearing properties of the turbidite fan in the Wenchang Formation 

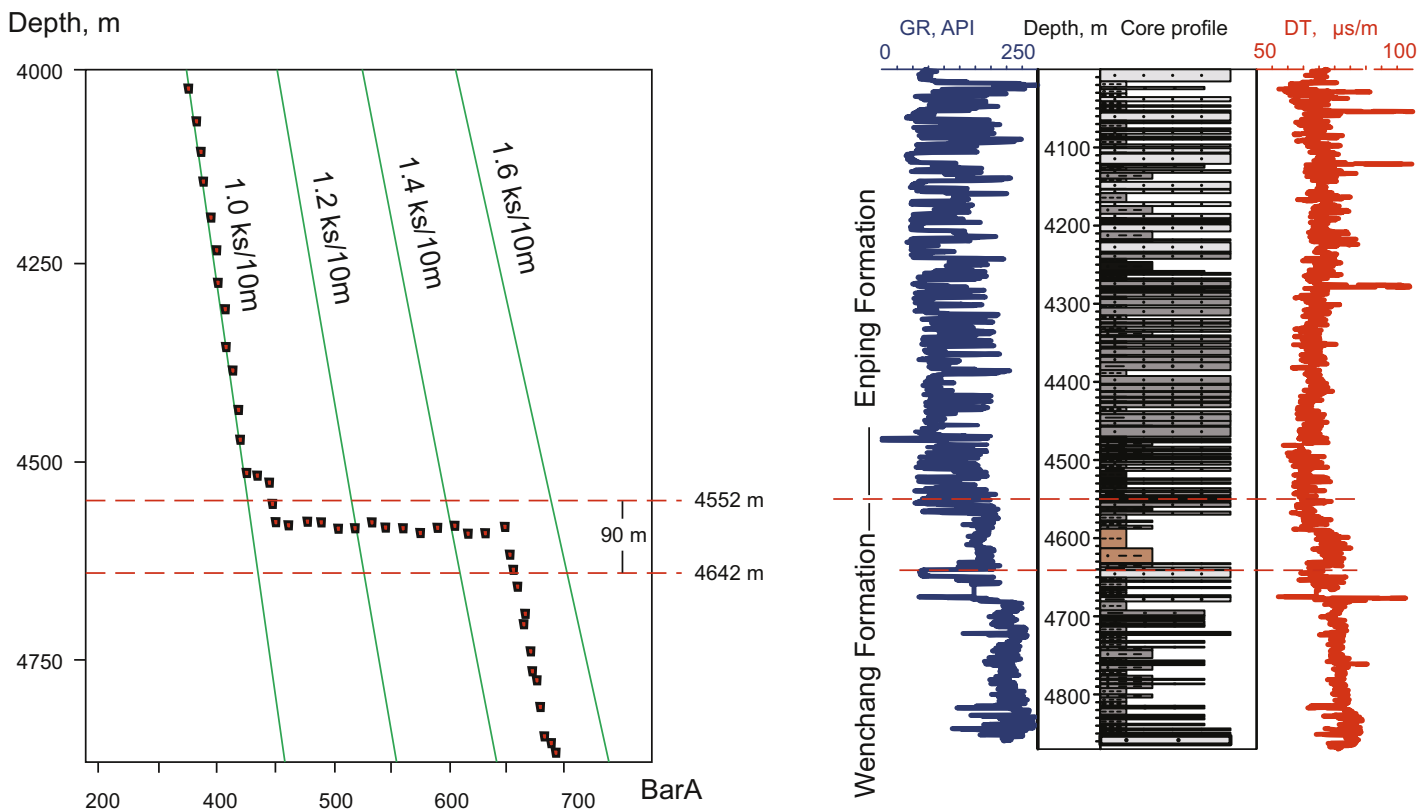

Fig. 13 Sharp increase in measured pressure within 4,552-4,642 m of well EP17-3-1 in the Enping Sag

quality of deep reservoirs in basins, with characteristics of high geothermal gradient and overpressure in deep layers. Abnormally high pressure was detected in the section where the turbidite fan developed in the Wenchang Formation of well EP17-3-1. Under abnormally high pressure conditions, produced by hydrocarbon generation, migration and accumulation, the reservoir physical properties of the fan were effectively preserved and improved to some extent. This fan had a burial depth of over 3,800 $\mathrm{m}$ when the Enping Sag entered the key hydrocarbon accumulation stage (Chen et al, 2008), and the reservoir properties are characterized by generally middle-low porosity and low permeability. The turbidite fan developed typically within lacustrine facies of the Wenchang Formation, was close to source rocks, and had good seal conditions. All factors mentioned above point out a promising future for oil and gas exploration of the Wenchang turbidite fan.

\section{Conclusions}

1) A sand-/mud-rich lacustrine turbidite fan in the Eocene Wenchang Formation has been studied. This fan, a set of normal grading sand beds, is interbedded within thick dark grey muddy source rocks of semi-deep to deep lake deposits. The fan covers an area of over $140 \mathrm{~km}^{2}$, and has a maximum thickness of $340 \mathrm{~m}$. The fan is sourced by mixed provenance from the north uplift zone in the north side of the Enping Sag and the Panyu low-uplift in the south side, and the sediments are primarily from the Panyu low-uplift.

2) The formation and development of the turbidite fan were controlled by multiple factors, including tectonic movement, source supply, slope topography and water depth. The second episode of the Zhuqiong movement is the most important factor in the formation of the turbidite fan, and the deepwater environment helps greatly in preserving the turbidite fan.
3) Seismic attribute characterization shows that the energy of low frequency is enhanced and energy of high frequency is weakened when seismic waves propagate through the oilbearing zone in this fan. AVO anomalies are shown in the seismic data and abnormally high pressures are encountered in 4,552-4,642 $\mathrm{m}$ of well EP17-3-1. The evidence reveals that hydrocarbons, generated from the Wenchang Formation, had migrated and accumulated into the turbidite fan. This fan is expected to be prospective for hydrocarbon exploration.

\section{Acknowledgements}

This study is financially supported by the China National Science and Technology Project (2011ZX05025-006). We are grateful to Xue Lianhua, Zhuo Xizhun, Jin Huijuan and Li Yuci from Lanzhou Center for Oil and Gas Resources, Institute of Geology and Geophysics, Chinese Academy of Sciences for comments on the work. CNOOC Research Center is thanked for providing the seismic and well data and permission to use and publish the proprietary data.

\section{References}

Bai G P and Zhang S W. Depositional patterns and oil/gas accumulation features of Sha-3 Member turbidites in Dongying Depression, Bohai Bay Basin. Petroleum Science. 2004. 1(2): 105-110

Chen G J, Lü C F, Li Y L, et al. Analysis of the oil and gas bearing turbidite within Wenchang Formation in Enping Depression, Pearl River Mouth Basin, China. Acta Sedimentologica Sinica. 2008. 26(5): 881-885 (in Chinese)

Chen Q H, Li W H, Gao Y X, et al. The deep-lake deposit in the Upper Triassic Yanchang Formation in Ordos Basin, China and its significance for oil-gas accumulation. Science China, Series D: Earth Sciences. 2007. 50(2): 47-58

Feng Z Q, Zhang S, Cross T A, et al. Lacustrine turbidite channels and fans in the Mesozoic Songliao Basin, China. Basin Research. 2010. 22(1): 96-107 
Fu N, Ding F, He S B, et al. Source rocks evaluation and reservoir characteristics analysis in Enping Sag, Pearl River Mouth Basin. China Offshore Oil and Gas. 2007. 19(5): 295-299 (in Chinese)

Gao Y X and Wu C Y. The sedimentary characteristics of the lacustrine fans in the Dawanhe oil bed of Liaohe Basin. Acta Sedimentologica Sinica. 1985. 3(4): 83-94 (in Chinese)

Huang L F. The application of sequence stratigraphy for analysis in nonmarine depression with example of Enping Sag, Pearl River Mouth Basin. China Offshore Oil and Gas. 1999. 13(3): 159-168 (in Chinese)

Huang Z J. Nonmarine source rock and petroleum formation of Pearl River Mouth Basin. China Offshore Oil and Gas. 1998. 12(4): 255261 (in Chinese)

Jackson C A L, Barber G P and Martinsen O J. Submarine slope morphology as a control on the development of sand-rich turbidite depositional systems: 3D seismic analysis of the Kyrre Fm (Upper Cretaceous), Måløy Slope, offshore Norway. Marine and Petroleum Geology. 2008. 25(8): 663-680

Jiang D X and Yang H Q. Original environment of Eogene petroleum source rocks in the Pearl River Mouth Basin. Acta Sedimentologica Sinica. 2000. 18(3): 469-474 (in Chinese)

Lai W Q and Gu J Y. Turbidity fan in the oil and gas-bearing basin in Bohai Bay. Acta Sedimentologica Sinica. 1984. 2(4): 47-57 (in Chinese)

Lei H Y, Zou W H, Wang L J, et al. The turbidite found in Chaxi Area and its importance for petroleum exploration. Acta Sedimentologica Sinica. 1999. 17(1): 89-94 (in Chinese)

Li Z W. The analysis of hydrocarbon accumulation conditions in Enping Sag. China Offshore Oil and Gas. 1999. 13(3): 174-180 (in Chinese)

Liu Z, Zhao Z Z, Zhao Y, et al. Predominant characteristics of formation and distribution for lithologic reservoirs in petroliferous basin. Acta Petrolei Sinica. 2006. 27(1): 17-23 (in Chinese)

Miao S D, Zhang G C, Liang J S, et al. Seismic reflection characteristics and sedimentary environment analysis of Wenchang Formation in Northern Depression of Zhujiangkou Basin. Natural Gas Geoscience. 2010. 21(5): 844-850 (in Chinese)

Pang X, Chen C M, Peng D J, et al. The Pearl River Deep-water Fan System \& Petroleum in South China Sea. Beijing: Science Press. 2007. 6 (in Chinese)

Pang X, Shen J, Yuan L Z, et al. Petroleum prospect in deep-water fan system of the Pearl River in the South China Sea. Acta Petrolei Sinica. 2006. 27(3): 11-16 (in Chinese)

Pettingill H S. Turbidite giants-lessons from the world's 40 largest turbidite discoveries. EAGE/AAPG 3rd Research Symposium, Abstracts Volume. 1998. AO27

Reading H G and Richards M. Turbidite systems in deep-water basin margins classified by grain size and feeder system. AAPG Bulletin. 1994. 78(5): 792-822
Redin T. Oil and gas production from submarine fans of the Los Angeles Basin. In: Biddle K T, ed., Active Margin Basin. AAPG Memoir. 1991. 239-259

Shanmugam G. 50 years of the turbidite paradigm (1950s-1990s): Deepwater processes and facies models - a critical perspective. Marine and Petroleum Geology. 2000. 17(2): 285-342

Shanmugam G. Ten turbidite myths. Earth-Science Reviews. 2002. 58(34): 311-341

Stow D A V and Mayall M. Deep-water sedimentary systems: New models for the 21 st century. Marine and Petroleum Geology. 2000. 17(2): $125-135$

Viana A, Figueiredo A, Faugères $\mathrm{J} C$, et al. The Sao Tomé deepsea turbidite system (southern Brazil Basin): Cenozoic seismic stratigraphy and sedimentary processes. AAPG Bulletin. 2003. 87(5): 873-894

Walker R G. Turbidites and submarine fans. In: Walker R G and James N P. Facies Models: Response to Sea Level Changes. Ottawa: Geological Association of Canada. 1992. 239-263

Wang J H, Liu L H, Chen S H, et al. Tectonic-sedimentary responses to the second episode of the Zhu-Qiong movement in the Enping Depression, Pearl River Mouth Basin and its regional tectonic significance. Acta Petrolei Sinica. 2011. 32(4): 588-595 (in Chinese)

Wang Y F, Wang Y M, Xu Q, et al. The early-middle Miocene submarine fan system in the Pearl River Mouth Basin, South China Sea. Petroleum Science. 2012. 9(1):1-9

Wang Y M, Xu Q, Li D, et al. Late Miocene Red River submarine fan, northwestern South China Sea. Chinese Science Bulletin. 2011. 56(14): 1488-1494

Wu C Y. Research Progress of Turbidite Deposits and Fan Deltas. Beijing: Petroleum Industry Press. 1986. 1-19 (in Chinese)

Zhang G C. Tectonic evolution of deepwater area of northern continental margin in South China Sea. Acta Petrolei Sinica. 2010. 31(4): 528533 (in Chinese)

Zhuo X Z, Wang Q, Chen G J, et al. Vertical porosity variation of clastic reservoir rock in Enping Sag, Pearl River Mouth Basin. Natural Gas Geoscience. 2007. 18(5): 643-647 (in Chinese)

Zhuo X Z, Wang Q, Chen G J, et al. Analysis of diagenetic process and dynamic reservoir assessment on the lower part of Enping Formation, Enping Sag. Acta Sedimentologica Sinica. 2008. 26(2): 257-264 (in Chinese)

Zhu W L, Wang Z F and Lü M. Exploration potential of atectonic oil-gas pools in the Northern shelf basin of the South China Sea. Petroleum Science. 2004. 1(2): 22-30

Zhu W L, Zhong K, Li Y C, et al. Characteristics of hydrocarbon accumulation and exploration potential of the northern South China Sea deep-water basins. Chinese Science Bulletin. 2012. 57(24): 3121-3129

(Edited by Hao Jie) 